Original scientific paper - Izvorni znanstveni rad

UDK: 636.23

\title{
Estimation of nonadditive genetic influences on standard lactation production (305 days) in upgrading of Serbian-Fleckvieh to Holstein-Friesian cattle breed
}

doi: 10.15567/mljekarstvo.2016.0409

\author{
Zolt Nemes ${ }^{1}$,Dragomir Lukač² ${ }^{*}$, M. Milan Petrović3 ${ }^{3}$ István Komlósi ${ }^{4}$, András Gáspárdy \\ 1PIK “Bečej”, Novosadska 2, 21220 Bečej, Serbia \\ ${ }^{2}$ University of Novi Sad, Faculty of Agriculture, Trg Dositeja Obradovića 8, 21000 Novi Sad, Serbia \\ ${ }^{3}$ Institute for Animal Husbandry, Autoput 16, 11080 Belgrade -Zemun, Serbia \\ ${ }^{4}$ University of Debrecen, Faculty of Agricultural and Food Sciences and Environmental Management, \\ Böszörményi 138, 4032 Debrecen, Hungary \\ ${ }^{5}$ Szent István University, Faculty of Veterinary Science, István 2, 1078 Budapest, Hungary
}

Received - Prispjelo: 25.01.2016. Abstract Accepted - Prihvaćeno: 20.10.2016.

The purpose of this paper is to estimate the effects of systematic factors, primarily the degree of crossing, on the standard lactation lengths of 305 days in 6 different genotypes of cows $\left(F_{1}, R_{1}, R_{2}, R_{3}\right.$, $\mathrm{R}_{4}, \mathrm{R}_{5}$ ) obtained by the upgrading of the Serbian Fleckvieh (SF) to the Holstein-Friesian (HF) breed of cattle. The systematic effects included in the general linear model (GLM) exerted a significant $(\mathrm{P}<0.05)$ influence on the milk yield, as well as the fat yield and content. During the upgrading process, statistically significant $(\mathrm{P}<0.05)$ differences were recorded between the traits of the genotypes examined. With an increase in the share of $\mathrm{HF}$ genes, the milk yield increased from $5020 \mathrm{~kg}\left(\mathrm{~F}_{1}\right)$ to $5801 \mathrm{~kg}\left(\mathrm{R}_{5}\right)$ and the fat yield from $176.2 \mathrm{~kg}$ to $201.6 \mathrm{~kg}$, whereas the fat content simultaneously decreased from $3.55 \%\left(\mathrm{~F}_{1}\right)$ to $3.49 \%\left(\mathrm{R}_{5}\right)$. The $\mathrm{F}_{1}$ cows had the highest heterosis realized $\left(h^{R}\right)$ regarding the milk yield (185.8 kg), while the $\mathrm{R}_{1}$ and $\mathrm{R}_{2}$ cows displayed negative heterosis effects $(-21.0$ and $-205.7 \mathrm{~kg}$ ) and negative recombination effects $\left(r^{r}\right)$. The highest value of $h^{R}$ (regarding the milk fat yield) was recorded in the $\mathrm{F}_{1}$ cows $(6.07 \mathrm{~kg})$ in comparison with the $\mathrm{R}_{2}$ cows, which had the negative $h^{R}(-3.79 \mathrm{~kg})$, whereas the negative $r^{I}$ was recorded in the $\mathrm{R}_{1}$ and $\mathrm{R}_{2}$ genotypes. The positive $r^{I}$ (regarding the milk fat content) was recorded in the $\mathrm{R}_{1}, \mathrm{R}_{2}$ and $\mathrm{R}_{3}$ genotypes accompanied by the positive $h^{R}$.

Key words: upgrading, crossbreeding, recombination, heterosis, standard lactation length

\section{Introduction}

Over the last few decades, considerable changes have occurred in the European dairy cattle production. Breeding aims and therefore breeding programs have been altered. Crossings with the upgrading method have changed the genetic structure of most combined breeds (McAllister 2002; Swalve et al., 2008) in the European countries (Lederer, 2005). In breeding, the most used breed has been the intensive dairy Holstein-Friesian (HF) breed, which originated from the North American continent (Cunningham, 1983). The countries which were breeding the traditional spotted cattle such as Switzerland, Hungary and Serbia, had the national breeding programs dictating the direction of cattle production development, which meant the introduction of the HF breed and upgrading the indigenous breed population to this breed. The significance of crossing the HF breed with the indigenous breeds was discussed by Wolf et al. (2005) in the instance of 
Czech spotted cattle and Schichtl (2007) in the instance of Bavarian spotted cattle, namely "Fleckvieh". According to Kräusslich (2002), the average share of HF genes in the Hungarian cow population in 1999 was only $1.65 \%$, whereas the share of HF genes in the Austrian cow population was 6.4 \% (Egger, 2005). According to Perišić (2008), the share of the Serbian Fleckvieh (SF) cattle breed amounts to around $70 \%$ in Serbia. The same author argues that in the period from 1990 to 2006 the milk yield within the standard lactation length was slightly increased from $4540 \mathrm{~kg}$ to $4660 \mathrm{~kg}$, which created a necessity for enhancing the breed.

Non-additive genetic effects (recombination and heterosis), which influence the productivity during the upgrading of dairy herds, are addressed in a limited number of studies. The primary reason lies in the data collection spanning over several decades. The very act of upgrading is very expensive and the end results cannot be reliably planned ahead. Moreover, the market treats the individuals of unknown genetic constitution and breeding value very indifferently, especially because each successive generation of crossed animals differ in body measures, productivity and technological requirements (Freyer et al., 2008). Lopez-Villalobos et al. (2000) state that the crossing and genetic variability may provide favorable advantages which substantially balance the production costs and market conditions.

The purpose of this paper is to assess the results of the upgrading of the SF to the HF breed of cattle according to the standard lactation features (such as milk yield, milk fat yield and content), to evaluate the non-additive genetic effects caused by crossing, and to determine the occurrence of gene recombination and heterosis.

\section{Materials and methods}

The population of animals studied consisted of 12,944 cows, sired by $390 \mathrm{HF}$ bulls (originating from Vojvodina-Bečej, Yugoslavia-Serbia, USA and Canada) and 8 SF bulls (originating from YugoslaviaSerbia and foreign countries), which were produced on seven farms in the same ownership in Vojvodina, Serbia, in the period from 1971 to 2008 . The crossing, i.e. the upgrading of the SF breed to the HF breed started in 1971. The whole process lasted until
2008, wherein six cow genotypes $\left(F_{1}, R_{1}, R_{2}, R_{3}, R_{4}\right.$ and $R_{5}$ ) with different proportions of the HF genes were obtained so that purebred HF cows could be produced eventually. The $\mathrm{F}_{1}$ cows were created by crossing the SF cows with the HF bulls which possessed $50 \%$ of HF genes. Each newer generation was produced by a consequent use of the HF semen. The crossbreeding process was conducted until receiving a cow generation with the HF blood proportion exceeding $99 \%$. As a result of many years of crossing, the following cow genotypes and HF gene proportions were obtained in order to produce the last generation of cows with $100 \%$ HF genes: $\mathrm{R}_{1}$ with $75 \%$ HF genes, $\mathrm{R}_{2}$ with $87.5 \% \mathrm{HF}$ genes, $\mathrm{R}_{3}$ with $93.75 \%$ $\mathrm{HF}$ genes, $\mathrm{R}_{4}$ with $96.88 \% \mathrm{HF}$ genes, $\mathrm{R}_{5}$ with $98.44 \%$ HF genes.

After examining the records of each cow, the proportion of HF genes (or the HF gene share within each genotype), the degree of crossing, the number of generations, the total production of milk, the amount of milk fat and the percentage of milk fat were determined.

The production traits within the standard lactation length (305 days) were analyzed by means of the following multiple-trait nested linear model:

$$
\begin{aligned}
\mathrm{Y}_{\mathrm{ijklmnopqrs}}= & \mu+\mathrm{K}_{\mathrm{i}}+\mathrm{B}_{\mathrm{j}}+\mathrm{S}_{\mathrm{k}}+\mathrm{E}_{1}+\mathrm{I}_{\mathrm{m}}+\mathrm{T}_{\mathrm{n}}+ \\
& \mathrm{P}_{\mathrm{o}}\left(\mathrm{K}_{\mathrm{i}}\right)+\mathrm{A}_{\mathrm{p}}\left(\mathrm{K}_{\mathrm{i}}\right)+\mathrm{Z}_{\mathrm{q}}+\mathrm{X}_{\mathrm{r}}+\mathrm{e}_{\mathrm{ijk} \text { lmnopqrs }}
\end{aligned}
$$

where: $Y_{i j k l m n o p q r s}=$ the mean value of the trait examined; $\mu=$ the overall mean value; $K_{i}=$ the genotype $(\mathrm{n}=8) ; B_{j}=$ the origin of the bull $(\mathrm{n}=6)$; $S_{k}=$ the number of parity $(\mathrm{n}=7) ; E_{l}=$ the year of calving $(\mathrm{n}=38) ; I_{m}=$ the period of calving $(\mathrm{n}=2)$; $T_{n}=$ the housing system $(\mathrm{n}=2) ; P_{o}=$ the service period (nested in the degree of crossing); $A_{p}=$ the age at first calving (nested in the degree of crossing); $Z=$ the year of bull's birth $(\mathrm{n}=48) ; X_{r}=$ the year of cow's birth $(\mathrm{n}=39) ; e_{i j k l m n o p q r s}=$ the error.

For the traits analyzed, the adjusted mean value (LSM - Least Square Means) was computed by the multiple-trait hierarchical linear model. The Duncan's post-hoc test for statistically significant differences among genotypes was applied (StatSoft, Inc. 2011). Moreover, the Dickerson-model (Dickerson 1969) was also applied for the estimate of the nonadditive crossing effects (Nemes et al., 2014). 


\section{Results and discussion}

Table 1 shows that all the systematic effects included in the model had a significant $(\mathrm{P}<0.05)$ influence on the milk yield, milk fat yield and fat content in the standard lactation length. The values of the coefficient of multiple correlation obtained during the data processing indicate a moderate correlation between the dependent variables (the milk yield $=0.61$, the milk fat yield $=0.59$ and the milk fat content $=0.61$ ) and the independent variables (the systematic effects) included in the model. The values of the coefficient of determination ranged from 0.32 to 0.37 . With regard to the milk yield and fat yield, slightly higher values (0.37 and 0.35$)$ were obtained compared to Marković's (1999) previous findings, who reported the values between 0.31 and 0.26 . However, the milk fat percentage results of this study were in accordance with his findings (0.32).

According to the $F$ values obtained (Table 2), the most important influence was exerted by the housing system $(\mathrm{F}=576.5)$ and the period of calving $(F=190.7)$. As in this study, other researchers (Vidović, 1990; Gáspárdy, 1995; Gaydarska et al., 2001; Petrović et al., 2012) confirmed the influence of systematic factors on dairy traits. White et al. (1981) reported that non-specific factors such as heard, year, season and their mutual interaction cause about 30 to $50 \%$ of variability in milk production within the standard lactation length.

Tables 3, 4 and 5 show the adjusted least square means (LSM) and the adjusted standard error of the mean $\left(\mathrm{SE}_{\mathrm{LSM}}\right)$ of the milk yield, fat yield and fat content within different cow genotypes. The results displayed in the tables indicate that the milk yield and milk fat increased with an increase in the share of HF genes in the cow's genotype, while the percentage of milk fat slightly decreased. Furthermore, it can be noticed that the standard error of the mean $\left(\mathrm{SE}_{\mathrm{LSM}}\right)$ of the traits analyzed decreased with the increase of HF genes, which can be explained by the increased number of cows with a higher share of HF genes in the population. Moreover, a significant increase in the milk production within different degrees of crossing was recorded, with the lower milk and milk fat production in the purebred HF breed compared to the $\mathrm{R}_{5}$ cows with the $98.45 \% \mathrm{HF}$ genes. Similar results were obtained by Kräusslich (1998), Heins et al. (2006), Dechow et al. (2007) and Perišić (2008).

Significant additive genetic differences in the milk amount (1834.9 kg) occurred between the HF and the SF breeds of cattle. Schmidlin (1979) has also confirmed the presence of significant additive genetic differences in the milk yield $(1387.0 \mathrm{~kg})$ between the Switzerland Simmental breed in comparison with the HF breed. Additive genetic differences of $1,383.0 \mathrm{~kg}$ in the milk yield of the German Spotted breed (GS) and the HF breed was reported by Schichtl (2007), and earlier Egger (2005) between the Austrian Spotted (AS) and the HF breed (of $1,232.0 \mathrm{~kg}$ ).

Table 3 indicates that the $\mathrm{F}_{1}$ cows had the positive and highest heterosis realized $\left(h^{R}\right)$ regarding the total milk yield with an amount of $185.8 \mathrm{~kg}$. Similar results were recorded by Schmidlin (1979) $(282.0 \mathrm{~kg})$, Egger (2005) (134.0 kg) and Schichtl (2007) (276.0 kg), respectively. The negative effect of recombination $\left(r^{r}\right)$ was determined in the $\mathrm{R}_{1}$ cows $(-113.9 \mathrm{~kg})$ and the $\mathrm{R}_{2}$ cows $(-252.2 \mathrm{~kg})$. Schmidlin (1979) confirmed a relatively important recombination loss of $383 \mathrm{~kg}$ in the milk production for within the standard lactation length. Later results of Egger (2005) also show the recombination losses in the milk production of the $R_{1}(-86 \mathrm{~kg})$ and $R_{2}(-64 \mathrm{~kg})$ genotypes.

Table 1. Analysis of the sum of squares

\begin{tabular}{ccccccc}
\hline Traits & $\mathrm{R}$ & $\mathrm{R}^{2}$ & $\mathrm{SS}$ & SS Res. & $\mathrm{F}$ & $\mathrm{P}$ \\
\hline Milk yield, $\mathrm{kg}$ & 0.61 & 0.37 & $2.534693 \mathrm{E}+10$ & $4.270396 \mathrm{E}+10$ & 206.59 & 0.000 \\
\hline Fat yield, $\mathrm{kg}$ & 0.59 & 0.35 & $2.320413 \mathrm{E}+07$ & $4.349862 \mathrm{E}+07$ & 185.67 & 0.000 \\
\hline Fat content, $\%$ & 0.57 & 0.32 & $6.373367 \mathrm{E}+02$ & $1.325074 \mathrm{E}+03$ & 167.41 & 0.000 \\
\hline
\end{tabular}

$\mathrm{R}$ - the multiple correlation coefficient, $\mathrm{R}^{2}$ - the multiple coefficient of determination, SS - the sum of squares of the model, SS Res. - the residual sum of squares 
Table 4 shows the amounts of milk fat gained from cows of different genotypes. The milk fat yield increased from $139.4 \mathrm{~kg}$ (SF) to $201.0 \mathrm{~kg}$ (HF) with an increase in the share of HF genes in the cow's genotype. The value of heterosis realized $h^{I}$ was the highest in the $\mathrm{F}_{1}$ cows $(6.07 \mathrm{~kg})$. In the instance of the $\mathrm{R}_{1}$ cows, a recombination loss $\left(r^{I}\right)$ of $-0.25 \mathrm{~kg}$ was lower than the expected heterosis $\left(h^{I}=3.04 \mathrm{~kg}\right)$, so the realized heterosis $\left(h^{R}=2.79 \mathrm{~kg}\right)$ was positive. The $\mathrm{R}_{2}$ cows had a higher recombination loss $(-5.31 \mathrm{~kg})$ in the milk fat yield than the expected heterosis $(1.52 \mathrm{~kg})$, so the heterosis realized was negative $(-3.79 \mathrm{~kg})$. In contrast, Schmidlin (1979) obtained a positive heterosis of $13.8 \mathrm{~kg}$ for the milk fat yield, while later Schichtl (2007) also obtained a positive heterosis of $19.75 \mathrm{~kg}$. We determined the recombination losses only in the $R_{2}$ cows, while the recombination losses in the milk fat yield within other genotypes were omitted. This is of great importance because milk fat yield is a primary parameter in milk price formation in many countries.

The results shown in Table 5 indicate a decrease in the milk fat content with an increase in the share of HF genes. Prior to the upgrading, the SF cows had $3.6 \%$ of milk fat, whereas, after six generation of crossing, that percentage decreased to $3.51 \%$ in the HF cows. In comparison with the HF genotype, the $R_{5}$ cows indicated the lowest milk fat content (3.49\%). In the $\mathrm{R}_{1}$ and $\mathrm{R}_{2}$ genotypes, positive recombination effects $\left(r^{I}\right)$ were determined for the milk fat content $(0.054$; and 0.047 respectively) with the positive results of realized $\left(h^{R}\right)$ and relative $\left(h^{r}\right)$ heterosis. In the crossing of $\mathrm{F}_{1}$ cows, Schmidlin (1979) recorded a positive heterosis realized of $0.06 \%$, whereas a higher heterosis realized of $2.7 \%$ was established later by Schichtl (2007), which was really high according the author. Fuerst and Sölkner (1994) have shown that the values of nonadditive components of variance for milk fat content and milk protein is almost the same, while the influence of dominance on variation of specific traits can be classified as constant provided more lactations are taken into account.

Table 2. Systematic effects on the milk traits

\begin{tabular}{ccc}
\hline Systemic effects & Wilk values & F values \\
\hline Genotypes & 0.997 & $3.8^{* * *}$ \\
\hline Origin of the bull & 0.992 & $23.1^{* * *}$ \\
\hline Number of parity & 0.957 & $64.9^{* * *}$ \\
\hline Year of calving & 0.707 & $86.5^{* * *}$ \\
\hline Period of calving & 0.979 & $190.7^{* * *}$ \\
\hline Housing system & 0.938 & $576.5^{* * *}$ \\
\hline Service period & 0.936 & $72.7^{* * *}$ \\
\hline Age at first calving & 0.998 & $2.6^{* * *}$ \\
\hline Bull's birth year & 1.000 & $4.0^{*}$ \\
\hline Cow's birth year & 0.997 & $28.0^{* * *}$ \\
\hline
\end{tabular}

${ }^{*} \mathrm{P}<0.05 ;{ }^{* *} \mathrm{P}<0.001$

Table 3. Milk yield within the standard lactation length of 305 days and non-additive genetic effects in different cow genotypes

\begin{tabular}{ccccccccc}
\hline $\begin{array}{c}\text { Geno- } \\
\text { type }\end{array}$ & $\begin{array}{c}\text { Share } \\
\text { of HF } \\
\text { gene, } \\
\%\end{array}$ & $\begin{array}{c}\text { No. of } \\
\text { lactation }\end{array}$ & $\begin{array}{c}\text { Milk yield, } \\
\mathrm{kg} \\
\mathrm{LSM} \pm \mathrm{SE}_{\mathrm{LSM}}\end{array}$ & $\begin{array}{c}\text { Expected } \\
\text { additive } \\
\text { superiority } \\
\text { of heterosis, } \\
\mathrm{kg}\left(h^{i}\right)\end{array}$ & $\begin{array}{c}\text { Additive } \\
\text { component } \\
\text { of heterosis, } \\
\mathrm{kg}\left(h^{I}\right)\end{array}$ & $\begin{array}{c}\text { Recombina- } \\
\text { tion, } \\
\mathrm{kg}\left(r^{I}\right)\end{array}$ & $\begin{array}{c}\text { Realized } \\
\text { heterosis, } \\
\mathrm{kg}\left(h^{R}\right)\end{array}$ & $\begin{array}{c}\text { Relative } \\
\text { heterosis, } \\
\%\left(h^{r}\right)\end{array}$ \\
\hline $\mathrm{SF}$ & 0.00 & 721 & $3917^{\mathrm{a}} \pm 108$ & - & - & - & - & - \\
\hline $\mathrm{F}_{1}$ & 50.00 & 785 & $5020^{\mathrm{b}} \pm 103$ & 917.5 & 185.8 & - & 185.8 & $3.84^{* * *}$ \\
\hline $\mathrm{R}_{1}$ & 75.00 & 825 & $5272^{\mathrm{c}} \pm 100$ & 1376.2 & 92.9 & -113.9 & -21.0 & $-0.40^{\mathrm{NS}}$ \\
\hline $\mathrm{R}_{2}$ & 87.50 & 649 & $5317^{\mathrm{d}} \pm 104$ & 160.5 & 46.5 & -252.2 & -205.7 & $-3.73^{* * *}$ \\
\hline $\mathrm{R}_{3}$ & 93.75 & 782 & $5712^{\mathrm{e}} \pm 102$ & 1720.2 & 23.2 & 51.1 & 74.3 & $1.32^{*}$ \\
\hline $\mathrm{R}_{4}$ & 96.87 & 2583 & $5760^{\mathrm{f}} \pm 91$ & 1777.5 & 11.6 & 53.5 & 65.1 & $1.14^{\mathrm{NS}}$ \\
\hline $\mathrm{R}_{5}$ & 98.45 & 5561 & $5801^{\mathrm{g}} \pm 89$ & 1806.2 & 5.8 & 72.4 & 78.2 & $1.37^{*}$ \\
\hline $\mathrm{HF}$ & 100.0 & 20116 & $5752^{\mathrm{f}} \pm 88$ & - & - & - & - & - \\
\hline
\end{tabular}

${ }^{*},{ }^{* *},{ }^{* * *}$ - number of subscribed stars show a significant difference from the Serbian Fleckvieh $\left({ }^{*} \mathrm{P}<0.05 ;{ }^{* *} \mathrm{P}<0.01\right.$;

$\left.*^{* * *} \mathrm{P}<0.001\right)$ : abcdefg - different letters in upper script indicates significant differences $(\mathrm{P}<0.05)$ 
According to Melchinger et al. (2007), the genetic basis of heterosis is not yet fully known, but the epistatic interactions of individual loci are most important components of heterosis in relation to parents. All the traits of the crossbred $\mathrm{F}_{1}$ progeny are partly under the influence of non-additive genes, i.e. dominance (interaction among the alleles of a single gene) and epistasis (gene interaction between loci), which means that in the $F_{1}$ generation, heterosis is a result of domination (mostly positive) and epistasis (often negative), as confirmed by Sörensen et al. (2008). Fuerst and Sölkner (1994) argue that, due to non-additive genetic effects, the crossed population differs from the initial population (or the breed used for crossing) particularly in the amount of produced milk. The results of our research confirm these findings. Boichard et al. (1993) argue that the offspring of the breeds which have close phylogenetic origin in crosses have a low heterosis with the milk production which generally ranges from 2.0 to $2.5 \%$. The results of this study are in accordance with the general experience in as much as the property with a low degree of inheritance achieves a higher degree of heterosis. If crossbred animals are

Table 4. Fat yield in the lactation of 305 days and the heterosis realized within genotypes

\begin{tabular}{ccccccccc}
\hline $\begin{array}{c}\text { Geno- } \\
\text { type }\end{array}$ & $\begin{array}{c}\text { Share } \\
\text { of } \\
\text { Hene, } \\
\%\end{array}$ & $\begin{array}{c}\text { No. of } \\
\text { lactation }\end{array}$ & $\begin{array}{c}\text { Fat yield, } \\
\mathrm{kg} \\
\mathrm{LSM} \pm \mathrm{SE}_{\mathrm{LSM}}\end{array}$ & $\begin{array}{c}\text { Expected } \\
\text { additive } \\
\text { superiority } \\
\text { of heterosis, } \\
\mathrm{kg}\left(h^{i}\right)\end{array}$ & $\begin{array}{c}\text { Additive } \\
\text { component } \\
\text { of heterosis, } \\
\mathrm{kg}\left(h^{r}\right)\end{array}$ & $\begin{array}{c}\text { Recombina- } \\
\text { tion, } \\
\mathrm{kg}\left(r^{r}\right)\end{array}$ & $\begin{array}{c}\text { Realized } \\
\text { heterosis, } \\
\mathrm{kg}\left(h^{R}\right)\end{array}$ & $\begin{array}{c}\text { Relative } \\
\text { heterosis, } \\
\%\left(h^{r}\right)\end{array}$ \\
\hline $\mathrm{SF}$ & 0.00 & 721 & $139.4^{\mathrm{a}} \pm 3.46$ & - & - & - & - & - \\
\hline $\mathrm{F}_{1}$ & 50.00 & 785 & $176.2^{\mathrm{b}} \pm 3.29$ & 30.78 & 6.07 & - & 6.07 & $3.53^{* * *}$ \\
\hline $\mathrm{R}_{1}$ & 75.00 & 825 & $188.4^{\mathrm{c}} \pm 3.22$ & 46.18 & 3.04 & -0.25 & 2.79 & $1.51^{*}$ \\
\hline $\mathrm{R}_{2}$ & 87.50 & 649 & $189.5^{\mathrm{d}} \pm 3.31$ & 53.88 & 1.52 & -5.31 & -3.79 & $-1.97^{* *}$ \\
\hline $\mathrm{R}_{3}$ & 93.75 & 782 & $200.2^{\mathrm{e}} \pm 3.25$ & 57.73 & 0.76 & 2.33 & 3.06 & $1.55^{*}$ \\
\hline $\mathrm{R}_{4}$ & 96.87 & 2583 & $201.3^{\mathrm{f}} \pm 2.92$ & 59.68 & 0.38 & 1.89 & 2.27 & $1.12^{\mathrm{NS}}$ \\
\hline $\mathrm{R}_{5}$ & 98.45 & 5561 & $201.6^{\mathrm{g}} \pm 2.85$ & 60.62 & 0.19 & 1.37 & 1.56 & $0.78^{\mathrm{NS}}$ \\
\hline $\mathrm{HF}$ & 100.0 & 20116 & $201.0^{\mathrm{f}} \pm 2.80$ & - & - & - & - & - \\
\hline
\end{tabular}

$*, * *, * * *$ - number of subscribed stars show a significant difference from the Serbian Fleckvieh $\left({ }^{*} \mathrm{P}<0.05 ;{ }^{* *} \mathrm{P}<0.011^{* * *} \mathrm{P}<0.001\right)$; abcdefg - different letters in upper script indicates significant differences $(\mathrm{P}<0.05)$

Table 5. Fat content in the lactation of 305 days and the heterosis realized within genotypes

\begin{tabular}{ccccccccc}
\hline $\begin{array}{c}\text { Geno- } \\
\text { type }\end{array}$ & $\begin{array}{c}\text { Share } \\
\text { of } \\
\mathrm{HF} \\
\text { gene, } \\
\%\end{array}$ & $\begin{array}{c}\text { No. of } \\
\text { lactation }\end{array}$ & $\begin{array}{c}\text { Fat content, } \\
\% \\
\mathrm{LSM} \pm \mathrm{SE}_{\mathrm{LSM}}\end{array}$ & $\begin{array}{c}\text { Expected } \\
\text { additive su- } \\
\text { periority of } \\
\text { heterosis, } \\
\%\left(h^{i}\right)\end{array}$ & $\begin{array}{c}\text { Additive } \\
\text { component } \\
\text { of heterosis, } \\
\%\left(h^{r}\right)\end{array}$ & $\begin{array}{c}\text { Recombina- } \\
\text { tion, } \\
\%\left(r^{r}\right)\end{array}$ & $\begin{array}{c}\text { Realized } \\
\text { heterosis, } \\
\%\left(h^{R}\right)\end{array}$ & $\begin{array}{c}\text { Relative } \\
\text { heterosis, } \\
\%\left(h^{r}\right)\end{array}$ \\
\hline $\mathrm{SF}$ & 0.00 & 721 & $3.60^{\mathrm{d}} \pm 0.019$ & - & - & - & - & - \\
\hline $\mathrm{F}^{1}$ & 50.00 & 785 & $3.55^{\mathrm{c}} \pm 0.018$ & -0.048 & -0.0090 & - & -0.009 & $-0.25^{\mathrm{NS}}$ \\
\hline $\mathrm{R}^{1}$ & 75.00 & 825 & $3.58^{\mathrm{d}} \pm 0.018$ & -0.072 & -0.0050 & 0.0540 & 0.049 & $1.39^{*}$ \\
\hline $\mathrm{R}^{2}$ & 87.50 & 649 & $3.56^{\mathrm{c}} \pm 0.018$ & -0.084 & -0.0030 & 0.0470 & 0.044 & $1.25^{\mathrm{NS}}$ \\
\hline $\mathrm{R}^{3}$ & 93.75 & 782 & $3.52^{\mathrm{b}} \pm 0,018$ & -0.090 & -0.0020 & 0.0020 & 0.000 & $0.00^{\mathrm{NS}}$ \\
\hline $\mathrm{R}^{4}$ & 96.87 & 2583 & $3.51^{\mathrm{b}} \pm 0.016$ & -0.093 & -0.0010 & -0.0050 & -0.006 & $-0.17^{\mathrm{NS}}$ \\
\hline $\mathrm{R}^{5}$ & 98.45 & 5561 & $3.49^{\mathrm{a}} \pm 0.016$ & -0.095 & -0.0005 & -0.0195 & -0.020 & $-0.27^{\mathrm{NS}}$ \\
\hline $\mathrm{HF}^{\mathrm{n}}$ & 100.0 & 20116 & $3.51^{\mathrm{b}} \pm 0.015$ & - & - & - & - & - \\
\hline
\end{tabular}

$*, * *, * *$ - number of subscribed stars show a significant difference from the Serbian Fleckvieh $\left({ }^{*} \mathrm{P}<0.05 ;{ }^{*} \mathrm{P}<0.01{ }^{* * *} \mathrm{P}<0.001\right)$; abcd - 'different letters in upper script indicates significant diferences $(\mathrm{p}<0.05)$ 
used for further breeding, recombination losses must be taken into account, i.e. significant non-additive effects of the opposite direction genes (which can be observed in the $\mathrm{R}_{1}$ and $\mathrm{R}_{2}$ genotypes).

\section{Conclusions}

The upgrading under conditions determined by certain systemic factors, based on the generally positive assessment of non-additive genetic effects (which affect the properties of the milk yield realized in the standard lactation length), can be justified. On the basis of the additive genetic effects (recombination and heterosis), the expected additive difference was increased during the upgrading. A positive heterosis was achieved owing to the fact that the actual realized production of crossed animals largely exceeded the expected additive superiority. With an increase in the share of Holstein-Friesian genes from generation to generation (accompanied by optimal zootechnical requirements and care), there was an increase in the total amount of milk within the standard lactation length of 305 days from $3917 \mathrm{~kg}$ in the SF breed to $5752 \mathrm{~kg}$ in the HF breed, the amount of milk fat from $139.4 \mathrm{~kg}$ to $201.0 \mathrm{~kg}$, and a decrease in the milk fat content from 3.60 to $3.51 \%$, respectively. Judging from our experiences on the farms in Vojvodina and all the above mentioned facts, it can be concluded that the upgrading method is very successful (despite decreasing trends) and results in a significant improvement of dairy herd traits.

\section{Procjena neaditivnih genetskih utjecaja na standardnu laktacijsku proizvodnju (305 dana) kroz poboljšanje domaćeg-šarenog goveda s holštajn-frizijskom pasminom goveda}

\section{Sažetak}

Cilj ovog rada bio je ispitati procjenu sistematskih faktora, prvenstveno stupnja križanja na standardnu laktacijsku proizvodnju od 305 dana kod 6 genotipova krava $\left(\mathrm{F}_{1}, \mathrm{R}_{1}, \mathrm{R}_{2}, \mathrm{R}_{3}, \mathrm{R}_{4} \mathrm{i} \mathrm{R}_{5}\right)$ dobivenih pretapanjem domaćeg šarenog goveda (SF) s holštajn- frizijskom (HF) pasminom goveda. Sistematski utjecaji uključeni u GLM model imali su značajan utjecaj $(\mathrm{P}<0,05)$ na količinu mlijeka, mliječne masti i postotak mliječne masti. Između dobivenih genotipova tijekom procesa pretapanja, zabilježene su statistički značajne razlike $(\mathrm{P}<0,05)$ u promatranim osobinama. S povećanjem udjela HF gena, povećavala se i količina mlijeka od $5020 \mathrm{~kg}$ kod $\mathrm{F}_{1}$ generacije do $5801 \mathrm{~kg}$ kod $\mathrm{R}_{5}$ generacije, mliječne masti od 176,2 do $201,6 \mathrm{~kg}$, dok je istovremeno došlo do pada postotka mliječne masti (od 3,55 \% kod $\mathrm{F}_{1}$ do ,49 \% kod $\mathrm{R}_{5}$ ). Krave $\mathrm{F}_{1}$ generacije su imale najveći realizirani heterozis $\left(h^{R}\right)$ za količinu mlijeka od $185,8 \mathrm{~kg}$, dok su krave genotipa $R_{1}$ i $R_{2}$ imale negativan realizirani heterozis $(-21,0$ odnosno $-205,70 \mathrm{~kg})$ pa samim tim i negativne rekombinacije $\left(r^{I}\right)$. Najveća realizirana vrijednost heterozisa $\left(h^{R}\right)$ za količinu mliječne masti je kod krava $F_{1}$ generacije $(6,07 \mathrm{~kg})$, u odnosu na krave $R_{2}$ generacije koje su imale negativan realizirani heterozis $(-3,79 \mathrm{~kg})$, a negativne rekombinacije su zabilježene kod krava $R_{1}$ i $R_{2}$ genotipa. Kod krava genotipa $\mathrm{R}_{1}, \mathrm{R}_{2} \mathrm{i} \mathrm{R}_{3}$ ustanovljene su pozitivne rekombinacije $\left(r^{I}\right)$ za postotak mliječne masti, uslijed čega su i realizirani heterozisi $\left(h^{R}\right)$ bili pozitivni.

\section{Ključne riječi: pretapanje, križanje, rekombinacija, heterozis, standardna laktacija}

\section{Acknowledgments}

In memory of Zlatko Skalicki, PhD, Professor at the Faculty of Agriculture in Zemun-Belgrade.

\section{References}

1. McAllister, A.J. (2002): Is Crossbreeding the Answer to questions of dairy breed utilization? Journal of Dairy Science 85, 2352-2357. doi: 10.3168/jds.S0022-0302(02)74315-4

2. Boichard, D., Bonati, B., Barbat, A. (1993): Effect of Holstein crossbreeding in the French Black and White cattle population, Journal of Dairy Science 76, 1157-1162. doi: 10.3168/jds.S0022-0302(93)77444-5

3. Dechow, C.D., Rogers, G.W., Cooper, J.B., Phelps, M.I., Mosholder, A.L. (2007): Milk, fat, protein, somatic cell score, and days open among Holsteins, Brown Swiss and their crosses, Journal of Dairy Science 90, 3542-3549. doi: 10.3168/jds.2006-889 
4. Dickerson, G. (1969): Experimental approaches in utilizing breed resources. Animal Breeding 37, 191-202.

5. Freyer, G., Konig, S., Fischer, B., Bergfeld, U., Cassell, B.G. (2008): Crossbreeding in dairy cattle from a German perspective of the past and today, Journal of Dairy Science 91, 3725-3743. doi: $10.3168 /$ jds.2008-1287

6. Fuerst, C.H., Sölkner, J. (1994): Additive and nonaddive genetic variances for milk yield, fertility, and lifetime performance traits of dairy cattle, Journal of Dairy Science 77, 1114-1125. doi: 10.3168/jds.S0022-0302(94)77047-8

7. Gáspárdy, A., Bozó, S., Dohy, J. (1995): Performance comparison of Hungarofries, Black Pied dairy cattle /SMR/ and Holstein Friesian breeds in Hungary, Archivfür Tierzucht 38, 247-266.

8. Gaydarska, V., Krustev, K., Simeonova, S., Ivanov, M. (2001): Influence of environmental and genetic factors on the milk yield and phenotypic and genotypic parameters of milk production in Black and White dairy cows in Bulgaria, Biotechnology in Animal Husbandry 17, 11-15.

9. Heins, B.J., Hansen, L.B., Seykora, A.J. (2006): Fertility and survival of pure Holsteins versus crossbreeds of Holstein with Normande, Montbeliarde, and Scandinavian Red, Journal of Dairy Science 89, 4944-4951. doi: 10.3168/jds.S0022-0302(06)72545-0

10. ICAR - International Committee for Animal Recording (2003): Guidelines approved by the General Assembly held in Interlaken, Switzerland, on 30 May 2002, Roma, $19-39$.

11. Kräusslich, H. (1998): Improvement of milk performance by different breeding strategies in the Hungarian, Swiss and Bavarian cattle population and future aspects of cattle breeding, Állattenyésztés és takarmányozás 47, 2.

12. Lederer, A.J. (2005): Kreuzungszucht bei Milch-und Zweinutzun grassen. Seminar des Ausschusses für genetik der ZAR, Salzubg, 37-51.

13. Lopez-Villalobos, N., Garrick, D.J., Blair, H.T., Holmes, C.W. (2000): Possible effects of 25 years of selection and crossbreeding on the genetic merit and productivity of New Zealand dairy cattle, Journal of Dairy Science 83, 154-163. doi: 10.3168/jds.S0022-0302(00)74866-1

14. Marković, M. (1999): Mixed models - BLUP and animal model to estimate breeding values of the HolsteinFriesian bulls. Ph.D. Thesis, University of Novi Sad.

15. Mc Daniel, B.T. (1969): Accuracy of sampling procedures for estimating lactation yields: A review, Journal of Dairy Science 52, 1742-1761. doi: 10.3168/jds.S0022-0302(69)86837-2
16. Melchinger, A.E., Utz, H.F., Piepho, H.P., Zeng, Z.B, Schon, C.C. (2007): The role of epistssis in the manifestation of heterosis: A systemsoriented approach, Genetics 177, 1815-1825. doi: 10.1534/genetics.107.077537

17. Nemes, Z., Vidović, V., Lukač D., Ivanković, A., Grubić, G., Komlósi, I., Gáspárdy, A. (2014): Estimation of nonadditive genetic impacts on lifetime performance through a grading-up breeding program with Holstein-Friesian, Mljekarstvo 64, 261-267. doi: 10.15567/mljekarstvo.2014.0405

18. Perišić, P. (2008): Reproductive and productive traits of Simmental breed in dual-purpose production and cowcalf system. Ph.D. Thesis, University of Belgrade.

19. Petrović, M.D., Petrović, M.M., Skalicki, Z., Bogdanović, V., Đoković, R., Rokanjac, S. (2012): The effect of interaction of systematic factors on milk performance of simmental cows in standard lactation, Biotechnology in Animal Husbandry 28, 67-75. doi: 10.2298/BAH1201067P

20. Schichtl, V. (2007): Einfluss der Kreuzung von Deutschen Holsteins und Deutschem Fleckvieh auf Milchleistung, Milchqualität und allge meine Gesundheits merkmale in einem automatischen Melk system. Ph.D. Thesis, University München.

21. Schmidlin, J.F. (1979): Ergebnisse von Populations analysen bei Simmental er Fleckvieh und dessen Kreuzungenmit Roten Holstein - Friesians. Ph.D. Thesis, University Zürih.

22. Sörensen, M.K., Norberg. E., Pedersen, J., Christensen, L.G. (2008): Invited rewiev: Crossbreeding in dairy cattle: A Danish perspective, Journal of Dairy Science 91, 4116-4128. doi: $10.3168 /$ jds.2008-1273

23. Swalve, H.H., Bergk, N., Solms-Lich, P. (2008): Crossbreeding in dairy cattle - Results from a practical farm. Zuchtungskunde 80, 429-442.

24. Vidović, V. (1990): Genetske promene u proizvodnji mleka i nekim svojstvima plodnosti holštajn goveda, Stočarstvo 44, 149-160.

25. White, J.M., Vinson, W.E., Pearson R.E. (1981): Dairy cattle improvement and Genetics, Journal of Dairy Science 64, 1305-1317. doi: 10.3168/jds.S0022-0302(81)82704-X

26. Wolf, J., Zavadilová, L., Némcová, E. (2005): Non-additive effects on milk production in Czech dairy cows, Journal of Animal Breeding and Genetics122, 332-339. doi: 10.1111/j.1439-0388.2005.00537.x 